\title{
Performance Testing of Radiobioassay Laboratories: In Vitro Measurements, Fecal Study Report
}

\author{
J. A. MacLellan
}

September 1988

Prepared for

the U.S. Department of Energy

Assistant Secretary for

Environment, Safety, and Health

under Contract DE-AC06-76RLO 1830

Pacific Northwest Laboratory

Operated for the U.S. Department of Energy

by Battelle Memorial Institute 


\title{
DISCLAIMER
}

This report was prepared as an account of work sponsored by an agency of the United States Government. Neither the United States Government nor any agency thereof, nor Battelle Memorial Institute, nor any or their employees, makes any warranty, expressed or implied, or assumes any legal liability or responsibility for the accuracy, completeness, or usefulness of any information, apparatus, product, or process disclosed, or represents that its use would not infringe privately owned rights. Reference herein to any specific commercial product, process, or service by trade name, trademark, manufacturer, or otherwise does not necessarily constitute or imply its endorsement, recommendation, or favoring by the United States Government or any agency thereof, or Battelle Memorial Institute. The views and opinions of authors expressed herein do not necessarily state or reflect those of the United States Government or any agency thereof.

\author{
PACIFIC NORTHWEST LABORATORY \\ operated by \\ BATTELLE MEMORIAL INSTITUTE \\ for the \\ UNITED STATES DEPARTMENT OF ENERGY \\ under Contract DE-AC06-76RLO 1830
}

\begin{tabular}{|c|c|}
\hline \multicolumn{2}{|c|}{ Printed in the United States of America } \\
\hline \multicolumn{2}{|c|}{ Available from } \\
\hline \multicolumn{2}{|c|}{ National Technical Information Service } \\
\hline \multicolumn{2}{|c|}{ United States Department of Commerce } \\
\hline \multicolumn{2}{|c|}{5285 Port Royal Road } \\
\hline \multicolumn{2}{|c|}{ Springfield, Virginia 22161} \\
\hline \multicolumn{2}{|c|}{ NTIS Price Codes } \\
\hline \multicolumn{2}{|c|}{ Microfiche A01 } \\
\hline \multicolumn{2}{|c|}{ Printed Copy } \\
\hline & Price \\
\hline Pages & Codes \\
\hline $001-025$ & $\mathrm{~A} 02$ \\
\hline $026-050$ & $\mathrm{~A} 03$ \\
\hline 051-075 & A04 \\
\hline $076-100$ & A05 \\
\hline $101-125$ & A06 \\
\hline $126-150$ & $\mathrm{~A} 07$ \\
\hline $151-175$ & A08 \\
\hline $176-200$ & A09 \\
\hline $201-225$ & A10 \\
\hline $226-250$ & A11 \\
\hline $257-275$ & A12 \\
\hline $276-300$ & A13 \\
\hline
\end{tabular}


PERFORMANCE TESTING OF RADIOBIOASSAY LABORATORIES: IN VITRO MEASUREMENTS, FECAL STUDY REPORT

J. A. MacLel1 1 an

September 1988

Prepared for

U.S. Department of Energy

Assistant Secretary for Environment, Safety, and Health

under Contract DE-AC06-76RLO 1830

Pacific Northwest Laboratory

Richland, Washington 99352 


\section{FOREWORD}

The U.S. Department of Energy (DOE) is concerned with occupational radiation protection of DOE and DOE-contractor employees. One area of special interest has been in the accuracy, quality control, and performance of bioassay laboratories. Bioassay measurements include in vitro excreta analysis and in vivo external counting.

A concern of DOE facilities and contractors is that bioassay laboratories may not be providing accurate and consistent results. To address this concern, the Health Physics Society Standard Committee Working Group 2.5 prepared a draft American National Standards Institute (ANSI) standard on bioassay laboratory performance, draft ANSI Standard N13.30, "Performance Criteria for Radiobioassay."(a)

Draft ANSI Standard N13.30 provides performance criteria in the form of an acceptable minimum detectable amount (AMDA), measurement bias $\left(B_{r}\right)$, and precision $\left(S_{A}\right.$ and $\left.S_{B}\right)$. Acceptable values for these criteria were reviewed and revised throughout the standard development process. While preparing the draft standard, DOE began to examine the feasibility of an accreditation program for bioassay laboratories serving its facilities and contractors. At present, DOE is assessing the potential implementation of an accreditation program.

DOE Order 5480.1, Chapter XI (DOE 1983) requires assessment of occupational radiation exposures. Accurate bioassay measurements are necessary to correctly determine intakes and internal exposure to radioactive materials. The estimation of internal contamination by plutonium and other actinides is a complex problem; often, both in vivo and in vitro analyses are employed. Although the vast majority of routine in vitro bioassay determinations are performed on urine, fecal analysis can provide greater sensitivity. Up to $40 \%$ of the original intake is excreted in the feces in the first few days following an inhalation incident.

(a) Draft ANSI Standard N13.30 is available from the Office of the Health Physics Society Executive Secretary, 800 Westpark Drive, Suite 400 , McLean, VA 22101. 
The project described in this report was sponsored by DOE to evaluate the draft standard performance criteria by testing the current fecal measurement capabilities of various bioassay laboratories. The project involved an intercomparison study using artificial fecal samples spiked with ${ }^{239} \mathrm{Pu}$ to test the analytical performance of the laboratories performing fecal analyses and to determine their capabilities to meet the minimum performance criteria specified in the draft standard. Results of this project have been made available to the committee preparing the standard. Thus, the acceptance values for the performance criteria in the standard are based, in part, on actual data from bioassay laboratories.

Three previous documents were published on the performance test results of related research projects: Performance Testing of Radiobioassay Laboratories: In Vitro Measurements, Pilot Study Report (Robinson, Fisher, and Hadley 1984); Performance Testing of Radiobioassay Laboratories: In Vivo Measurements, Pilot Study Report (Robinson et al. 1986); and Performance Testing of Radiobioassay Laboratories: In Vitro Measurements, Final Report (MacLellan, Traub, and Fisher 1988). This report summarizes the project, details the artificial fecal sample preparation, and presents the results of the in vitro fecal testing program.

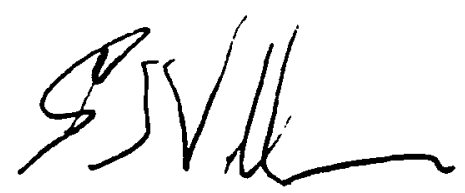

E. J. Vallario Acting Director Radiological Controls Division Office of Nuclear Safety U.S. Department of Energy 


\section{$\underline{\text { ABSTRACT }}$}

This study evaluated nine radiobioassay laboratories' performances in analyzing fecal samples to determine the samples' levels of radioactivity. The project was undertaken as a review of draft ANSI Standard N13.30, "Performance Criteria for Radiobioassay." A total of 135 artificial fecal samples were sent to nine laboratories. Each laboratory received five samples spiked with $9.58 \mathrm{pCi}$ of ${ }^{239} \mathrm{Pu}$, five samples spiked with $1.13 \mathrm{pCi}$ of ${ }^{239} \mathrm{Pu}$, and five unspiked blank samples. Four of the laboratories returned data for all samples; four reported they were unable to complete the analyses; one analyzed six samples (three blanks and three of the lower activity samples). Results reported by the laboratories were analyzed by statistical methods specified in the draft standard for relative bias, relative precision, and minimum detectable activity (MDA).

The calculated relative biases of all laboratories were well within the criteria of the standard $(-0.25$ to +0.5$)$. Biases for three laboratories were about $5 \%$ and the two others were within $\pm 20 \%$. Relative precision statistics for all participating laboratories were lower than the acceptance criteria of the standard $(40 \%)$. Relative precision was less than $15 \%$ for one laboratory; for two others, it was less than 10\%; and for the remaining two, it was less than $5 \%$ of the acceptance criteria. For the MDA criterion, four of the five laboratories passed. For all four of the passing laboratories, the entire $90 \%$ confidence interval was less than the specified acceptable minimum detectable amount (acceptable MDA) of $1 \mathrm{pCi}$. For the fifth laboratory, the MDA was $80 \%$ above the acceptable MDA specified in the draft standard. 


\section{EXECUTIVE SUMMARY}

The U.S. Department of Energy Order 5480.1, Chapter XI (DOE 1983) requires assessment of occupational radiation exposures. Accurate bioassay measurements are necessary to correctly determine intakes and internal exposure to radioactive materials. The DOE is concerned with the quality of measurements that are used to determine exposure levels of workers to sources of radioactivity; it sponsors research at the Pacific Northwest Laboratory (PNL) and elsewhere to improve standards for radioactive measurements. of specific interest have been the accuracy and precision of radiation dosimeters, radiation survey instruments, and bioassay laboratories.

The purpose of this project is to evaluate draft ANSI Standard N13.30, "Performance Criteria for Radiobioassay."(a) Study findings were previousiy made available to the group preparing the draft standard in establishing appropriate and reasonable performance criteria.

Draft ANSI Standard N13.30 provides quantitative performance criteria for bias, precision, and minimum detectable activity (MDA) for a selected list of measurement categories and commonly assayed radionuclides. It provides standard quality control procedures for the internal quality assurance programs at radiobioassay laboratories. It also provides guidelines to be used by a future laboratory for testing whether bioassay service laboratories conform to both the quantitative performance criteria for bias and precision and to such standard quality control procedures as might be required for laboratory accreditation.

In this study, a total of 135 artificial fecal samples were sent to nine laboratories for analysis. Each participant received five samples spiked with $9.58 \mathrm{pCi}$ of ${ }^{239} \mathrm{Pu}$ (about 10 times the acceptable MDA of $1 \mathrm{pCi}$ specified in the draft standard), five samples spiked with $1.13 \mathrm{pCi}$ of ${ }^{239} \mathrm{Pu}$, and five unspiked blank samples. Participants also received a cover letter explaining special handling instructions and a results report form. The artificial fecal

(a) Draft ANSI Standard N13.30 is available from the Office of the Health Physics Society Executive Secretary, 800 Westpark Drive, Suite 400, McLean, VA 22101. 
sample matrix was developed from published data on natural fecal composition and artificial excreta. Each sample consisted of $30 \mathrm{~g}$ of solids and about $20 \mathrm{~g}$ of water. Four of the nine participating laboratories returned data for all samples; four participants reported they were unable to complete the analyses; one other laboratory analyzed only six samples (three blanks and three low-activity samples).

Results reported by the participants were analyzed by the statistical methods specified in the draft standard (i.e., those for relative bias, relative precision, and MDA). In accordance with the draft ANSI N13.30, failure to meet any one of the criteria resulted in failure for the performance test. There were no failures for the relative bias and relative precision criteria, and the $95 \%$ confidence intervals for these criteria were completely within the acceptance region.

For the MDA criterion, four of the five laboratories (80\%) passed. For all four of the passing laboratories, the entire 90\% confidence interval was less than the specified acceptable minimum detectable amount (acceptable MDA), $1 \mathrm{pC}$. For the fifth laboratory, the PNL-calculated MDA was $80 \%$ above the acceptable MDA.

Results of this study of fecal analysis performance tests are similar to those of previous studies of urinalysis (Robinson, Fisher, and Hadley 1984) and in vivo counting (Robinson et al. 1986). The calculated relative biases for all laboratories were well within the criteria of the standard $(-0.25$ to $+0.5)$. Biases for three laboratories were about $5 \%$ and the two others were within $\pm 20 \%$.

Relative precision statistics for all participating laboratories were also lower than the acceptance criteria of the standard (40\%). Relative precision was less than $15 \%$ for one laboratory; for two, it was less than $10 \%$; and for the remaining two, it was less than $5 \%$ of the acceptance criteria. Three laboratories passed the MDA criterion with calculated MDA values that were less than $10 \%$ of the AMDA and one additional passed with an MDA less than the acceptable MDA. One laboratory failed the MDA criterion. 
Specific recommendations are as follows:

- The present acceptance criteria for relative bias and relative precision are appropriate for the evaluation of laboratories performing fecal analysis for ${ }^{239} \mathrm{Pu}$.

- Artificial fecal material provides an appropriate test matrix and should be used for accreditation testing.

- The MDA-calculation procedure should be custom-fitted to the measurement procedure and the performance testing procedure itself.

- Although the relative bias and relative precision statistical indicators are easily applied and interpreted, MDA interpretation requires greater knowledge of the underlying assumptions. The testing laboratory personnel should consider the statistical interdependence of parameters of the analysis (efficiency, recovery, etc.) and the degrees of freedom of the estimate of the standard deviation for the analysis. 


\section{ACKNOWLEDGMENTS}

We would like to acknowledge the sponsor of the research program, the U.S. Department of Energy (DOE) Radiological Controls Division, Edward J. Vallario, Acting Director. We also acknowledge the help of Drs. Larry Lucas and Ken Inn of the National Bureau of Standards, who supplied the standard solution of plutonium for this study.

The intercomparison study is a task under the Internal Dosimetry Evaluation and Upgrade Project at the Pacific Northwest Laboratory (PNL). The overall occupational radiation protection research program at PNL is managed by Jack M. Selby of PNL's Health Physics Department. Jack Selby has provided overa 11 management and research direction for this study since its inception in 1981 .

We wish to extend appreciation to our technical editor, Jim Weber, and to our word processors, Lyn Myers and Claudia Burk.

Finally, we wish to thank the laboratories who were willing to participate in this study. Because of their participation, we were able to provide the Health Physics Society Working Group 2.5 with invaluable information on performance capabilities of active service laboratories. This information provides the basis for a workable, practicable standard, from which the entire bioassay community will benefit. 


\section{CONTENTS}

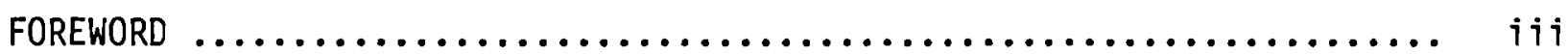

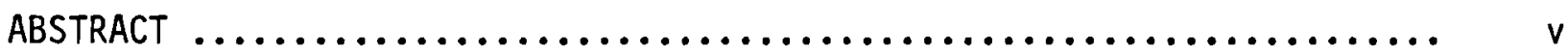

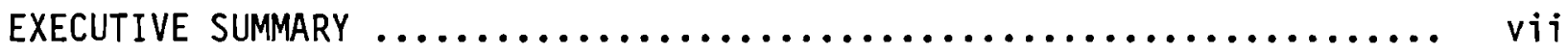

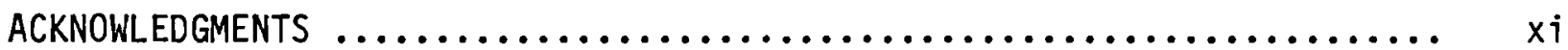

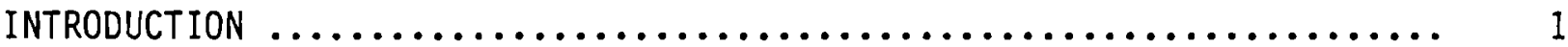

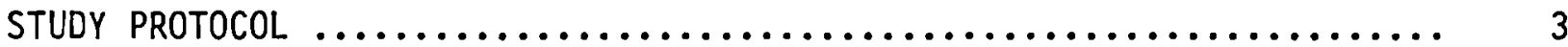

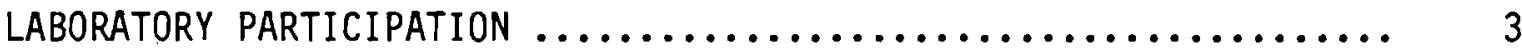

ARTIFICIAL FECAL SAMPLE PREPARATION $\ldots \ldots \ldots \ldots \ldots \ldots \ldots \ldots \ldots \ldots \ldots \ldots \ldots \ldots$

SAMPLE IDENTIFICATION AND DISTRIBUTION $\ldots \ldots \ldots \ldots \ldots \ldots \ldots \ldots \ldots, 5$

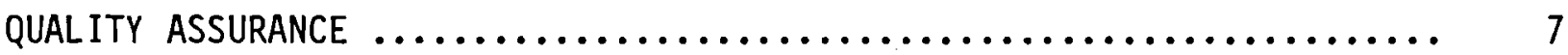

STATISTICAL INDICATORS OF MEASUREMENT PERFORMANCE $\ldots \ldots \ldots \ldots \ldots \ldots \ldots . . \ldots$

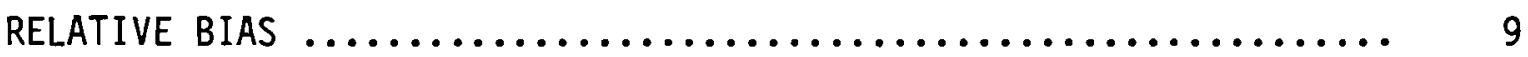

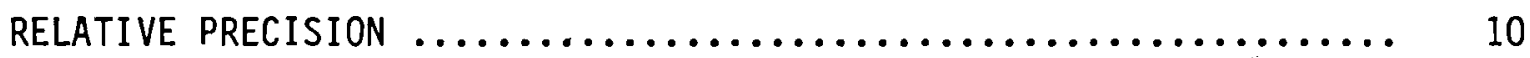

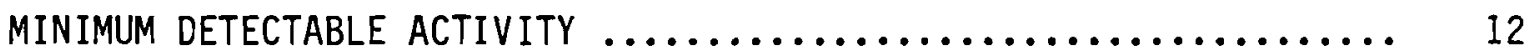

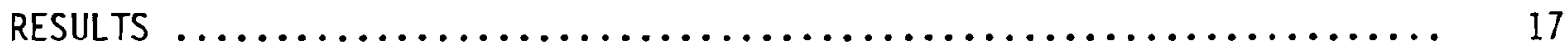

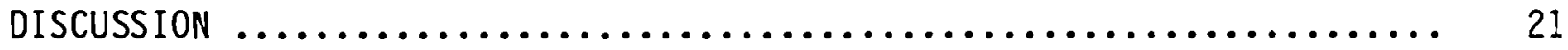

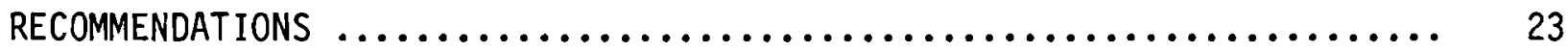

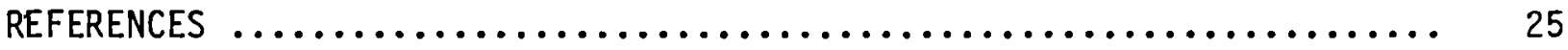

APPENDIX A - LETTER OF INQUIRY $\ldots \ldots \ldots \ldots \ldots \ldots \ldots \ldots \ldots \ldots \ldots \ldots \ldots \ldots \ldots \ldots \ldots \ldots \ldots \ldots . .1$

APPENDIX B - IN VITRO MEASUREMENTS REPORT FORM $\ldots \ldots \ldots \ldots \ldots \ldots \ldots \ldots$ B. 1

APPENDIX C - PROPAGATION OF ERROR IN SPIKED

ARTIFICIAL FECAL SAMPLES $\ldots \ldots \ldots \ldots \ldots \ldots \ldots \ldots \ldots \ldots \ldots$ C.I

APPENDIX D - PARTICIPANT-SUPPLIED DATA $\ldots \ldots \ldots \ldots \ldots \ldots \ldots \ldots \ldots \ldots \ldots \ldots \ldots \ldots \ldots \ldots$ 


\section{FIGURES}

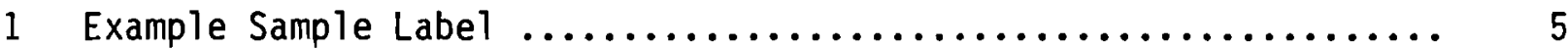

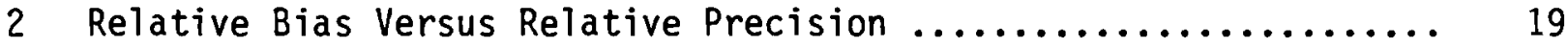

3 PNL-Calculated Minimum Detectable Amounts ................... 19

\section{TABLES}

1 Artificial Fecal Matrix Recipe for One Sample $\ldots \ldots \ldots \ldots \ldots \ldots . . .4$

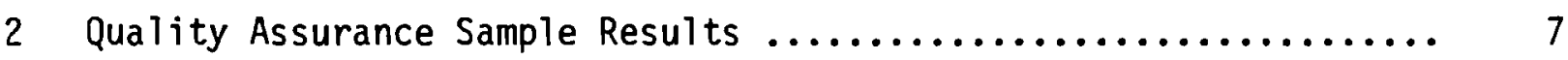

3 Performance Criteria Results .............................. 18 


\section{INTRODUCTION}

The accuracy and precision of radiation measurements is of primary importance. Radiation protection measurements include field measurements, personnel dosimetry, and bioassay measurements to document compliance with allowable exposure levels and to estimate dose following accidental intakes. Calibration techniques, quality control procedures, human factors, and quality of the detector systems employed all affect measurement results.

This project, undertaken for the Department of Energy (DOE) by Pacific Northwest Laboratory (PNL), (a) studied the performance of radiobioassay laboratories. Results of this study, covering the laboratories' fecal analysis, were used in the preparation of ANSI Standard N13.30, "Performance Criteria for Radiobioassay."

Radiobioassay is a procedure used to determine the intake of radioactive materials in humans. In vivo counting, or "direct bioassay," involves measurements of radiation emitted from the body using external detector systems. In vitro sample analysis, or "indirect bioassay," involves the measurement of radioactivity in urine, feces, or other biological materials taken from the body. A combination of indirect and direct bioassay is most often used to estimate a worker's burden of internally deposited radionuclides.

The varied physical/chemical forms of radionuclides in the workplace require different radioanaiytic techniques and procedures, but certain aspects of radiation program management are common to all forms. These include quality control procedures and recordkeeping. Measurement performance specifications include values for minimum detectable activity (MDA), precision, and accuracy. In order to establish standards of bioassay performance upon which a uniform national program of performance testing might be based, the Health Physics Society Standards Committee formed Working Group 2.5 under the chairmanship of Kenneth R. Heid to prepare the draft ANSI Standard N13.30, "Performance Criteria for Radiobioassay." The draft standard was completed and submitted to the Health Physics Society standards committee in 1986.

(a) Pacific Northwest Laboratory is operated by Battelle Memorial Institute for the U.S. Department of Energy under Contract DE-AC06-76RLO 1830. 
The primary reason for instituting a performance standard was that bioassay service laboratories, both commercial and private (including institutional laboratories), may not be providing accurate results for analyses performed. A number of factors may contribute to analytical inaccuracies:

- Current analytical procedures may not be adequate to obtain correct results.

- Quality assurance may be deficient.

- Management may lack motivation to upgrade and improve analytical capabilities.

- Economic considerations may prevent obtaining adequate instrumentation.

- Uniform performance criteria, applicable to the variety of analytical procedures in use, may not be available.

For a selected list of measurement categories and commonly assayed radionuclides, draft ANSI Standard N13.30 provides quantitative performance criteria for bias, precision, and MDA. It also provides standard quality control procedures for the internal quality assurance programs of radiobioassay laboratories. It contains guidelines, as well, to be used by a future laboratory for testing whether bioassay service laboratories conform both to the quantitative performance criteria for bias and precision and to such standard quality control procedures as might be required in a test for laboratory accreditation.

Previous PNL studies have investigated the appropriateness of the standard criteria for the urinalysis and in vivo counting categories. This study investigates the appropriateness of criteria for the fecal analysis category. 
STUDY PROTOCOL

The fecal bioassay study followed the same general protocol as previous performance tests conducted as a part of the PNL evaluation of draft ANSI Standard N13.30 (Robinson, Fisher, and Hadley 1984; Robinson et a1. 1986; MacLellan, Traub, and Fisher 1988).

\section{LABORATORY PARTICIPATION}

Letters of inquiry (Appendix A) were sent to $16 \mathrm{DOE}$ and DOE-contractor laboratories that had participated in previous PNL bioassay studies and were believed to be involved in fecal radiobioassay. Participation was voluntary and results confidential. Twelve laboratories responded; nine expressed interest in participating in the fecal analysis study.

A total of 135 test samples were sent to the nine laboratories. Each participant received five samples spiked with $9.58 \mathrm{pCi}$ of ${ }^{239} \mathrm{Pu}$ (about 10 times the acceptable MDA specified in the draft standard), five samples spiked with $1.13 \mathrm{pCi}$ of ${ }^{239} \mathrm{Pu}$, and five unspiked blank samples. Participants also received special handling instructions and a report form (Appendix $B$ ).

\section{ARTIFICIAL FECAL SAMPLE PREPARATION}

The artificial matrix used for the samples was developed by PNL from published data on natural fecal composition (Altman and Dittmer 1974; Straub and Bond 1974; ICRP 1974) and artificial excreta (Besik 1971; Kester 1973; and Shoupp, Dingess, and Moe 1981). Each sample consisted of $30 \mathrm{~g}$ of solids and about $20 \mathrm{~g}$ of water (Table 1). The normal water content of feces (70\%) was not attainable owing to the noncellular nature of the matrix. A significant volume of natural feces is made up of dead cells and live bacteria. The difference in moisture content was not considered a problem because chemical preparation and radioanalysis of fecal samples are normally preceded by wet ashing with nitric acid, which quickly lyses all cell membranes. 


\section{TABLE 1. Artificial Fecal Matrix Recipe}

\begin{tabular}{lc}
\multicolumn{1}{c}{ Reagent } & Mass, g \\
\cline { 3 - 3 } Calcium hydroxide & 0.97 \\
Ferric ammonium sulfate & 0.04 \\
Magnesium carbonate & 0.61 \\
Potassium carbonate & 0.83 \\
Ammonium dihydrogen phosphate & 2.1 \\
Sodium sulfate & 0.37 \\
Ammonium chloride & 0.04 \\
Zinc sulfide & 0.01 \\
Stannous sulfide & 0.03 \\
Leucine & 7.1 \\
Lysine & 5.1 \\
Methionine & 0.8 \\
Threonine & 2.0 \\
Palmitic acid & 3.0 \\
Stearic acid & 2.0 \\
Oleic acid & 1.0 \\
Cellulose & 4.0 \\
Water & $\underline{20.0}$ \\
$\quad$ Total & 50.0
\end{tabular}

The ${ }^{239} \mathrm{Pu}$ spike solution was prepared from a National Bureau of Standards (NBS) calibrated standard solution. Measured masses of the NBS solution were diluted to two spike solution concentrations of $1.041 \mathrm{pCi} / \mathrm{g}$ and $8.785 \mathrm{pCi} / \mathrm{g}$.

Each test sample of artificial fecal material was prepared individually because spiking a large batch of the artificial fecal matter did not provide assurance that the radioactivity was uniformly distributed throughout the solids; samples drawn from such a batch could vary appreciably. Individual test samples were prepared as follows: 
1. Solid matrix ingredients, in quantities sufficient to prepare 200 samples, were placed in a drum tumbler and tumbled for 24 hours to assure uniform mixing.

2. Approximately $20 \mathrm{~mL}$ water was added to a plastic sample bag.

3. A calibrated re-pipette was used to add $1 \mathrm{~mL}(1.09 \mathrm{~g})$ of the diluted NBS spike solution to the water.

4. Approximately $30 \mathrm{mg}$ of the mixed matrix solids were added to the bag.

5. The bag was sealed with double heat seals at the top and bottom.

6. Bag contents were mixed by kneading the bag.

Overall error for the assumed sample activity was estimated to be less than $2 \%$. Each participant was sent 15 samples. Five samples were unspiked blanks, five contained $1.13 \mathrm{pCi}$, and five contained $9.58 \mathrm{pCi}$ of ${ }^{239} \mathrm{Pu}$.

SAMPLE IDENTIFICATION AND DISTRIBUTION

Participants were assigned a unique code designator, A through I. Codes were used throughout the study to identify all samples and data. Prior to loading, each sample bag was labeled with the information shown in Figure 1.

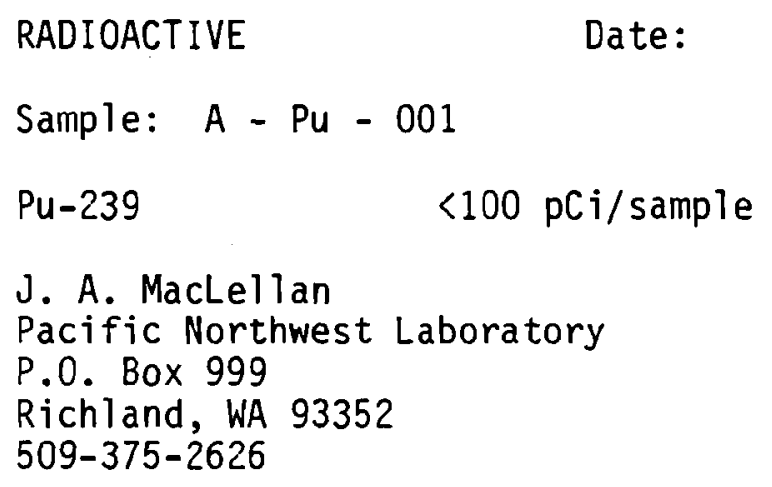

FIGURE 1. Sample Label

The sample code (e.g., A- Pu - 001) incorporates the laboratory code, the test radionuclide, and the sample number. The 15 samples were boxed and shipped to the participating laboratories along with the report form in Appendix $B$. 


\section{QUALITY ASSURANCE}

The calibrated solution used to spike the test samples was obtained from the NBS as ${ }^{239} \mathrm{Pu}$ in approximately 5 molar hydrochloric acid. This solution had an estimated error of $0.72 \%$ associated with the calibration. The overall error of each test sample was less then $1 \%$ when calculated in accordance with the error propagation equations of Appendix $C$.

Prior to preparing the large sample batch for the test samples, a small sample batch was prepared for procedure verification and quality assurance. Three samples were spiked and submitted to the Chemical Technology Department at PNL for analysis (Table 2). The reported results were consistent with an accurate and reproducible spiking procedure.

\section{TABLE 2. Quality Assurance Sample Results}

\begin{tabular}{|c|c|c|c|}
\hline & \multicolumn{3}{|c|}{ Sample Number } \\
\hline & 1 & 2 & 3 \\
\hline Activity added, $\mathrm{pCi}$ & 8.80 & 7.69 & 11.36 \\
\hline Reported results, $\mathrm{pC} \mathbf{i}$ & 8.87 & 7.25 & 11.28 \\
\hline Relative bias & 0.008 & -0.057 & -0.007 \\
\hline Average relative bias & -0.019 & & \\
\hline Standard deviation of bias & 0.034 & & \\
\hline
\end{tabular}




\section{STATISTICAL INDICATORS OF MEASUREMENT PERFORMANCE}

It is generally accepted that a bioassay laboratory should be able to provide adequate assurance that reported results are consistentiy reproducible and accurately measured down to reasonably low levels. A consensus, would be more difficult to obtain, though, on what should constitute the acceptable numerical limits for these concepts. The National Council on Radiation Protection and Measurements (NCRP) recommended that accuracy of measurements should be within $\pm 30 \%$ (NCRP 1978), but other documents discuss measurement quality assurance practices without specifying acceptable performance (ANSI 1973, 1978).

Draft ANSI Standard N13.30 provides performance criteria for judging the quality of analyses performed by a radiobioassay laboratory. Performance is judged by three specific criteria: the relative bias, the relative precision, and the MDA of a measurement procedure for a particular radionuclide. The following sections review how these criteria are calculated and indicate the acceptable levels for each criterion.

\section{RELATIVE BIAS}

The relative bias is a statistical indicator of how close the measurement results are to the true activity in a sample. Since the actual activity must be known to calculate this number and since this is rarely known in samples from human subjects, the relative bias can be calculated only for measurements on samples which have been spiked with known amounts of radioactivity.

The draft standard defines the relative bias, $B_{r i}$, for a single measurement as follows:

$$
B_{r i}=\frac{A_{i}-A_{a i}}{A_{a i}}
$$

where $A_{i}$ is the measured activity of the ith sample, and $A_{a j}$ is the activity or amount added to the $i$ th sample. For $N$ measurements, the relative bias, $B_{r}$, is defined as the average of relative biases for the individual samples: 


$$
B_{r}=\frac{1}{N} \sum_{i=1}^{N} B_{r i}
$$

where $B_{r i}$ is as defined in Equation (1).

The draft standard sets the acceptable range for relative bias at $-25 \%$ to $+50 \%$. The asymmetrical range was established to acknowledge that most errors are multiplicative (multiply or divide by a factor) rather than additive.

\section{RELATIVE PRECISION}

The relative precision is a statistical indicator of the variability of results for an analytical procedure. It is estimated by analyses of replicate samples containing known and equal quantities of radioactive material or, in the case of in vivo bioassay, by repeated counts of a single sample.

It is desirable to establish bias and precision indicators that are statistically independent of each other so that changes in the bias do not affect the precision indicator. Two statistics have been proposed. The standard deviation of sample measurements divided by the average measurement value was defined in the draft standard as $S_{A}$ :

$$
S_{A}=\frac{\left[\sum_{i=1}^{N}\left(A_{i}-\bar{A}\right)^{2} /(N-1)\right]^{1 / 2}}{\bar{A}}
$$

where $A_{j}$ is as defined for Equation (1), and $A$ is the mean measured activity for $N$ samples as shown below:

$$
\bar{A}=\frac{1}{N} \sum_{i=1}^{N} A_{i}
$$


To make $S_{A}$ usable over more than one activity testing level, Equation (4) was manipulated algebraically to place the denominator term within the summation. It can then be rewritten as

$$
S_{A}=\left[\sum_{j=1}^{M} \sum_{i=1}^{N}\left(A_{i j} / A_{j}-1\right)^{2} /(M(N-1))\right]^{1 / 2}
$$

where $\quad M=$ the number of radioactivity categories

$$
\begin{aligned}
N= & \text { the number of samples per category } \\
A_{i j}= & \text { the measured activity for the } i \text { th sample in the } j \text { th } \\
& \text { category } \\
A_{j}= & \text { the mean measured value for the } j \text { th category } \\
\bar{A}_{j}= & \frac{1}{N} \sum_{i=1}^{N} A_{i j}
\end{aligned}
$$

The relative standard deviation of sample measurements at some true spike level, divided by the true spike level, was defined in the draft standard as $S_{B}$.

$$
S_{B}=\frac{\left[\sum_{i=1}^{N}\left(A_{i}-A\right)^{2} /(N-1)\right]^{1 / 2}}{A_{a i}}
$$

where $N, A_{i}, A_{a i}$, and $\bar{A}$ are as defined above.

It was also shown that the above equation is algebraically equivalent to the standard deviation of the bias estimators for a group of measurements:

$$
S_{B}=\left[\sum_{i=1}^{N}\left(B_{r i}-B_{r}\right) \xi(N-1)\right]^{1 / 2}
$$

where $B_{r}$ and $B_{r i}$ are as defined previously. 
Past analyses of the relative bias and relative precision statistical indicators, however, have shown that their independence is predicated upon the type of error predominating (Brodsky 1986). When multiplicative errors predominate (errors associated with efficiency, sample size, yield), the errors cancel out of the equation for $S_{A}$, and $B_{r}$ and $S_{A}$ are independent. Likewise, when additive errors predominate, as with changes in background levels, $B_{r}$ and $S_{B}$ are considered independent. Because the predominate errors are often not identified, both indicators have been incorporated into the standard. The acceptance range for relative precision has been set at less than or equal to $40 \%$ for both $S_{A}$ and $S_{B}$.

\section{MINIMUM DETECTABLE ACTIVITY}

To ensure that a laboratory can detect the presence of radioactivity in quantities small enough to maintain doses and the associated risk within acceptable levels, the standard also establishes acceptable minimum detectable amounts (acceptable MDAs). Although no single equation is appropriate for all measurement procedures, the standard does provide the basic assumptions on which an MDA equation must be based and gives suggested equations which will be applicable to most situations.

The main MDA equation discussed in the draft standard is

$$
M D A=\left(4.65 s_{b}+3\right) / a E R T
$$

where $s_{b}=$ standard deviation of the blank count

$a=$ appropriate conversion factor for decay per unit time to activity units (i.e., $2.22 \mathrm{dpm} / \mathrm{pCi}$ )

$E$ = counting equipment efficiency factor

$R=$ chemical recovery factor

$T$ = counting time. 
The $4.65 \mathrm{~s}_{\mathrm{b}}$ term results from doubling the critical level. The null hypothesis that the sample and the blank counts are the same is rejected at the $95 \%$ level. The components of this term are

$$
2 K s_{0}=2 K\left[2 s_{b}^{2}\right]^{1 / 2}
$$

where $s_{0}$ is the standard deviation of the net blank count, and $K$ is the 95th percentile of the standard normal variate. The value ' 3 ' in the MDA equation results from the derivation of the formula and is the rounded value of the square of the $95 \%$ value of the standard normal deviate (1.645). This term is necessary since the Poisson variance is proportional to the mean; therefore, the variance of the sample counts will be larger than the variance of the blank counts (Currie 1984). If the variance were constant, the MDA would equal $4.65 \mathrm{~s}_{b}$. The ' 3 ' term also provides a lower bound for the MDA when $s_{b}$ approaches zero.

Four basic assumptions are inherent in Equation (8) (Currie 1984):

1. The probabilities of both false positives and false negatives are $5 \%$ or less.

2. Non-Poisson errors are insignificant.

3. Standard deviation of the blank may be estimated by the square root of the total counts for the blank.

4. Net counts are determined by paired observations (blank counting time equal to the sample counting time).

If the variance of the blank count rate contains significant non-Poisson variability, but the blank count rate has been determined to be stable and is estimated from the average value obtained from replicate analyses, the 4.65 factor in Equation (8) should be replaced with the following expression:

$$
2 t(n)^{1 / 2}
$$


where $t$ is the value of the " $t$ " statistic for the appropriate degrees of freedom, and

$$
\eta=\left[\frac{(1+b)}{b}\right]^{1 / 2}
$$

with $b$ as the ratio of the sample counting time to the total counting time used to estimate the blank count rate. When a sample is compared to a single blank count, $2 t(n)^{1 / 2}$ equals 6.03 . When five replicates are used to estimate the standard deviation of the blank and the sample is compared to the mean of the blanks, $2 t(n)^{1 / 2}$ equals 4.66 and the t-estimate equation and the basic equation give equivalent results.

If the efficiency or recovery factors show significant variability and they are not determined for each sample, Section 4.3.1 of draft ANSI N13.30 specifies use of the lower $5 \%$ bound of the product of aERT (aERT .05). The calibration factors generally follow a log-normal distribution so that a log transform should be performed on the data set prior to calculating the standard deviation.

Aga in in accordance with Section 4.3.1 of draft ANSI N13.30, if tracers are added to each sample and the product of efficiency and chemical recovery is included in the determination of each blank, then $s_{b} /(a E R T)$ may be replaced in the MDA equation by $s_{b}{ }^{\prime} / a T$, where $s_{b}{ }^{\prime}$ is the standard deviation of the quotient of the blank count and the product of efficiency and chemical recovery. The remaining terms in the denominator are constants which will not affect $s_{b}$ '. Since all participants in this study used tracers for each sample and $s_{b}$ ' was estimated from replicate counts, the MDA equation used for this study is as follows:

$$
M D A=2 t(\eta)^{1 / 2} s_{b}{ }^{\prime} / a T+3 /\left[a(E R) 0.05^{\top}\right]
$$

where all terms are as defined above. 
The ' 3 ' term in the MDA equation limits Type II errors (false negatives) to $5 \%$ when $s_{b}$ ' is near zero. The ' 3 ' term has units of counts and is converted to units of activity using the lower $5 \%$ bound of the distribution of the calibration factor $\left[(E R)_{.05}\right]$. The values of ' $a$ ' and ' $T$ ' remain constant and are not included in the distribution.

The MDA calculated as described above may be interpreted as a mean value for the measurement procedure. If a confidence interval is desired, the chi-square distribution may be used, as described in Currie (1984).

The acceptable MDAs specified in the draft standard for each test category and nuclide were established after evaluating both needs related to health physics and the present capabilities of competent radiobioassay laboratories. The draft standard acceptance criterion for fecal analysis of ${ }^{239} \mathrm{Pu}$ is $1 \mathrm{pC}$ i per sample. 


\section{RESULTS}

Four of the nine laboratories returned data for all samples sent. Four participants reported they were unable to complete the analyses. One other laboratory could analyze only six samples (three blanks and three low-activity samples).

Reported assay results for each sample measurement are given in Appendix $D$. These data were analyzed by the statistical methods specified in the draft standard (i.e., relative bias, relative precision, and MDA). Table 3 shows the calculated values of relative bias, relative precision, and MDA. Failure to meet any one of the criteria resulted in failure for the performance test.

Figure 2 is a plot of the relative bias versus relative precision for each laboratory. There were no failures for these criteria and the $95 \%$ confidence intervals for relative bias and relative precision were within the acceptance region.

Figure 3 shows the PNL-calculated MDA for each laboratory. For this criterion, four of the five laboratories (80\%) passed. For all four of these laboratories, the entire $90 \%$ confidence interval was less than the specified acceptable MDA ( $1 \mathrm{pC} i)$. For the fifth laboratory, the PNL-calculated MDA was 80\% above the acceptable MDA and the entire confidence interval exceeded $1 \mathrm{pCi}$. 
TABLE 3. Performance Criteria Results

\begin{tabular}{|c|c|c|c|c|c|c|c|c|}
\hline \multirow[b]{2}{*}{$\begin{array}{c}\text { Laboratory } \\
\text { Code } \\
\end{array}$} & \multirow[b]{2}{*}{$\begin{array}{l}\text { Sample } \\
\text { Number }\end{array}$} & \multirow[b]{2}{*}{$A_{a i}, p C i$} & \multirow[b]{2}{*}{${ }^{B} r$} & \multirow[b]{2}{*}{$\mathrm{S}_{\mathrm{B}}$} & \multirow[b]{2}{*}{$S_{A}$} & \multicolumn{3}{|c|}{ MDA, $p C i$} \\
\hline & & & & & & $\begin{array}{c}\text { Lower } \\
5 \% \\
\text { Bound } \\
\end{array}$ & Mean & $\begin{array}{l}\text { Upper } \\
95 \% \\
\text { Bound } \\
\end{array}$ \\
\hline$A$ & $1-5$ & 0.00 & -- & --- & --- & 0.022 & 0.025 & 0.036 \\
\hline$A$ & $51-55$ & 1.13 & 0.067 & 0.068 & 0.064 & -- & & \\
\hline A & $101-105$ & 9.58 & 0.057 & 0.074 & 0.070 & --- & & \\
\hline$A$ & TOTAL &.-- & 0.062 & 0.067 & 0.063 & -- & & \\
\hline B & \multicolumn{2}{|c|}{ NO DATA RETURNED } & & & & & & \\
\hline c & \multicolumn{2}{|c|}{ NO DATA RETURNED } & & & & & & \\
\hline D & \multicolumn{2}{|c|}{ NO DATA RETURNED } & & & & & & \\
\hline$E$ & \multicolumn{2}{|c|}{ NO DATA RETURNED } & & & & & & \\
\hline $\mathrm{F}$ & $26-30$ & 0.00 & -- & -- & -- & 0.013 & 0.019 & 0.041 \\
\hline$F$ & $76-80$ & 1.13 & -0.066 & 0.041 & 0.044 & --- & & \\
\hline $\mathrm{F}$ & $126-130$ & 9.58 & -0.185 & 0.063 & 0.078 &.-- & & \\
\hline$F$ & TOTAL & $-\cdots$ & -0.125 & 0.080 & 0.059 & --- & & \\
\hline G & $31-35$ & 0.00 & --- & -- & -- & 1.2 & 1.8 & 4.2 \\
\hline G & $81-85$ & 1.13 & 0.078 & 0.173 & 0.160 & -- & & \\
\hline G & $131-135$ & 9.58 & 0.171 & 0.125 & 0.107 & --- & & \\
\hline G & TOTAL & --- & 0.124 & 0.150 & 0.128 & -.- & & \\
\hline$H$ & $36-40$ & 0.00 & --- & -- & --- & 0.30 & 0.44 & 1.0 \\
\hline$H$ & $86-90$ & 1.13 & 0.023 & 0.036 & 0.036 & --- & & \\
\hline$H$ & $136-140$ & 9.58 & 0.017 & 0.044 & 0.044 & $\ldots$ & & \\
\hline$H$ & TOTAL & $-\cdots$ & 0.020 & 0.038 & 0.037 & $\cdots$ & & \\
\hline I & $41,43,45$ & 0.00 & -- & -- & -- & 0.057 & 0.093 & 0.35 \\
\hline I & $92,93,94$ & 1.13 & 0.036 & 0.013 & 0.012 & --- & & \\
\hline
\end{tabular}




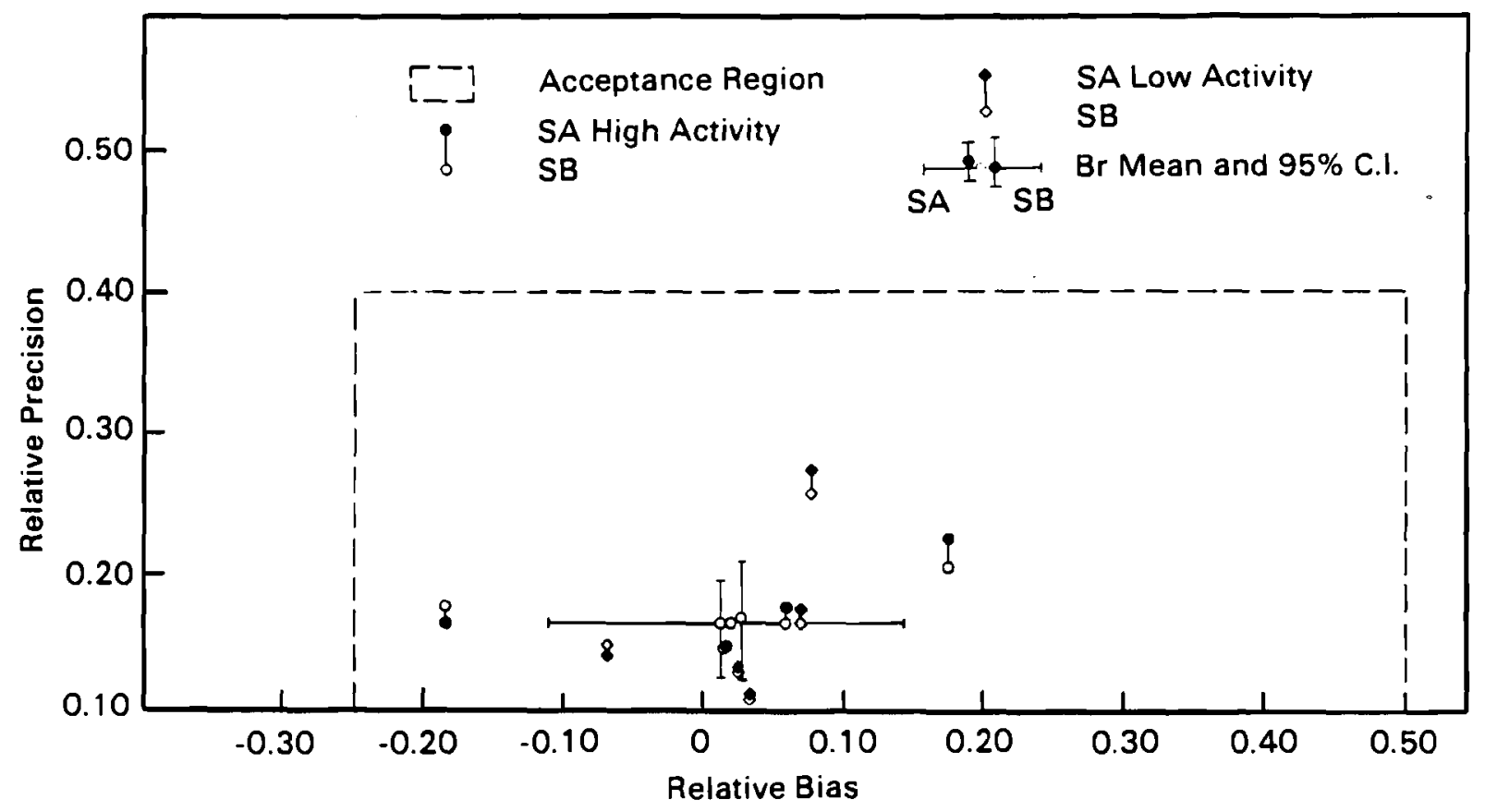

FIGURE 2. Relative Bias Versus Relative Precision

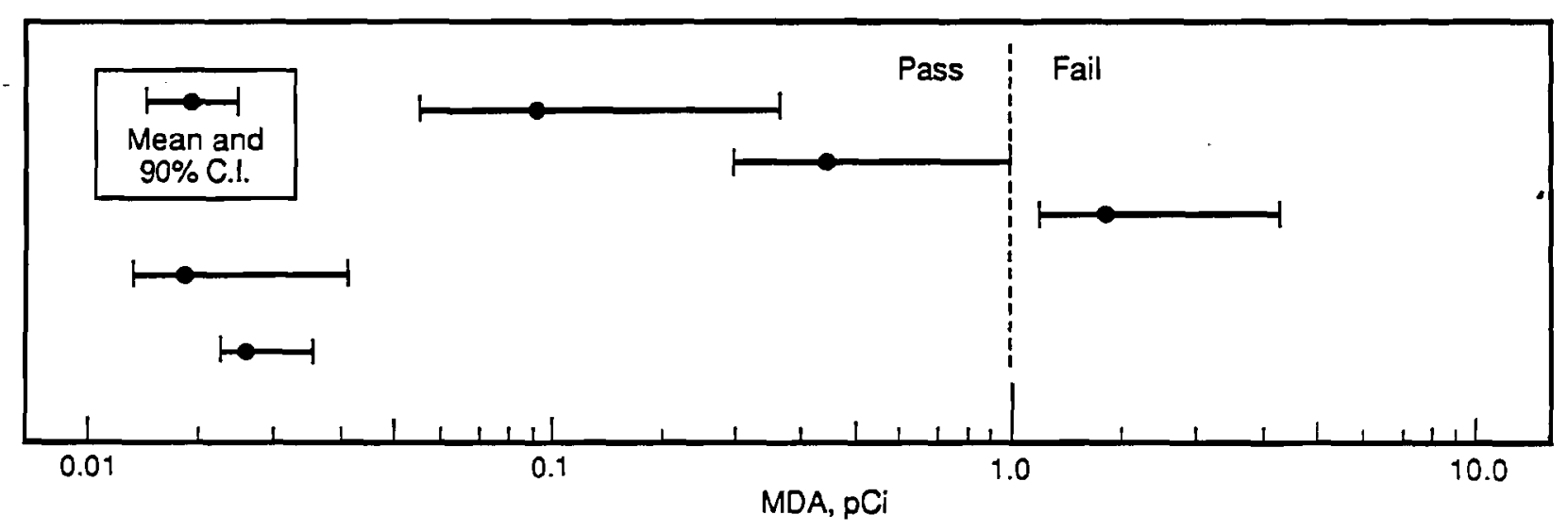

FIGURE 3. PNL-Calculated Minimum Detectable Amounts 


\section{DISCUSSION}

Results for the fecal analysis performance tests are similar to those for urinalysis and in vivo counting (Robinson, Fisher and Hadley 1984; Robinson et al. 1986; MacLellan, Traub, and Fisher 1988). Relative bias and relative precision criteria were easily met, while calculated MDAs for some laboratories were greater than the acceptable amount. The calculated relative biases for all laboratories were well within the criteria of the standard $(-0.25$ to +0.5$)$. Biases for three laboratories were about $5 \%$ and the two others were within the $\pm 20 \%$ range.

For all participating laboratories, the relative precision of analyses was also much less than the $40 \%$ acceptance criterion of the standard. For one laboratory, relative precision was less than 15\%; for two, it was less than $10 \%$; and for the remaining two, it was less than $5 \%$. In all cases the $S_{A}$ and $S_{B}$ statistics for any given laboratory differed by less than $3 \%$.

Three laboratories passed the MDA criterion with calculated MDA values that were less than $10 \%$ of the acceptable MDA, and one additional laboratory passed with an MDA about half the acceptable MDA. The laboratory failing the MDA criterion reported data for one blank sample analysis that was much larger than their mean reported value. If the analysis result was an example of a true "outlier," it might be appropriate to exclude it from the calculations. If it were excluded, the laboratory would pass the MDA criterion. This should not be done, however, unless there is a known cause for the error, such as a mistake in purification of the analyte. To exclude it without a thorough process evaluation could hide significant systematic errors in the analysis procedure and grossly underestimate the MDA. 


\section{RECOMMENDATIONS}

The primary objective of this project is to evaluate the appropriateness of the performance criteria specified in draft ANSI Standard N13.30. Secondly, the study findings are used to develop recommendations for changes in the standard.

Frequent discussions took place between members of the project team and members of the Health Physics Society Working Group 2.5 preparing the draft standard. Project representatives attended all meetings of the working group to ensure that the intercomparison testing corresponded to the recommendations of the draft standard. Project staff members provided numerous suggestions for improving the draft standard during these meetings. Many of the following recommendations were incorporated or are currently under consideration by the working group:

- additional definitions of terms

- selection of categories and radionuclides for in vitro testing

- changes in acceptance criteria

- descriptions of quality control procedures

- use of artificial feces test matrix

- reformulation of performance criteria statistics. Specific recommendations formulated in response to results of the fecal analysis study are as follows:

- The present acceptance criteria for relative bias and relative precision are appropriate for the evaluation of laboratories performing fecal analys is for ${ }^{239} \mathrm{Pu}$.

- The artificial fecal material provides an appropriate test matrix and should be used for accreditation testing.

- The MDA calculation procedure should be custom-fitted to the measurement procedure being evaluated and the performance testing procedure itself. 
- Although the relative bias and relative precision statistical indicators are easily applied and interpreted, MDA interpretation requires greater knowledge of the underlying assumptions. Consideration should be given to the statistical interdependence of parameters of the analysis (efficiency, recovery, etc.) and the degrees of freedom of the estimate of the standard deviation for the analysis.

- The 4.65 factor in the MDA equation should be replaced with $2 t(\eta) \frac{1}{2}$ if the variance of the blank count rate contains significant non-Poisson variability, and the blank count rate, which has been determined to be stable, is estimated from the average value obtained from replicate analyses. When efficiency and recovery are estimated for each sample the MDA equation should be as follows:

$$
M D A=2 t(n)^{\frac{1}{2}} s_{b}{ }^{\prime} / a T+3 /\left[a(E R) .05^{\top}\right]
$$




\section{REFERENCES}

Altman, P. L., and D. S. Dittmer, eds. 1974. Biology Data Book. Vol. 3. 2nd ed., pp. 1489-1490, Federation of American Societies for Experimental Biology, Bethesda, Maryland.

American National Standards Institute (ANSI). 1973. Thyroid Radioiodine Uptake Measurements Using a Neck Phantom. ANSI N44.3-1973, New York.

American National Standards Institute (ANSI). 1978. American National Standard for Internal Dosimetry for Mixed Fission and Activation Products. ANSI N343-1978, New York.

Besik, F. 1971. "Waste Water Reclamation in a Closed System." Water and Sewage Works 188(7):213-220.

Brodsky, A. 1986. Accuracy and Detection Limits for Bioassay Measurements in Radiation Protection - Statistical Considerations. NUREG-1156, U.S. Nuclear Regulatory Commission, Washington, D.C.

Currie, L. A. 1984. Lower Limit of Detection: Definition and Elaboration of a Proposed Position for Radiological Effluent and Environmental Measurements. NUREG/CR-4007, U.S. Nuclear Regulatory Commission, Washington, D.C.

International Commission on Radiological Protection (ICRP). 1974. Report of the Task Group on Reference Man. ICRP Report No. 23, Oxford, England.

Kanipe, L. G. 1977. Handbook of Analytical Quality Control in Radioanalytical Laboratories. PB-277-251, U.S. Department of Commerce, Technical Information Service, Washington, D.C.

Kester, F. L. 1973. Central Waste Processing System. SVHSER 6224, National Aeronautics and Space Administration, Houston, Texas.

MacLellan, J. A., R. J. Traub, and D. R. Fisher. 1988. Performance Testing of Radiobioassay Laboratories: In Vitro Measurements, FinaT Report.

PNL-6490, Pacific Northwest Laboratory, Richland, Washington.

National Council on Radiation Protection and Measurements (NCRP). 1978. Instrumentation and Monitoring Methods for Radiation Protection. NCRP Report No. 57, Washington, D.C.

Robinson, A. L., D. R. Fisher, and R. T. Hadley. 1984. Performance Testing of Radiobioassay Laboratories: In Vitro Measurements, Pilot Study Report. NUREG/CR-3809, DOE/NBM 1071, PNL-5248, U.S. Nuclear Regulatory Commission/U.S. Department of Energy, Washington, D.C. 
Robinson, A. L., D. R. Fisher, W. D. Reece, and J. A. MacLellan. 1986. Performance Testing of Radiobioassay Laboratories: In-Vivo Measurements Pilot Study Report. PNL-5840, Pacific Northwest Laboratory, Richland, Washington.

Shoupp, W. J., J. M. Dingess, and P. G. Moe. 1981. Microbial Purification of Recycled Wastewater. PB82-153693, Office of Water Research and Technology, Washington, D.C.

Straub, C. P., and R. G. Bond eds. 1974. Wastewater: Treatment and Disposal. Vol. 4 of CRC Handbook of Environmental Control. CRC Press, Cleveland, Ohio.

U.S. Department of Energy (DOE). 1983. "Requirements for Radiation Protection." In DOE Order 5480.1, Chap. 11. Washington, D.C. 
APPENDIX A

LETTER OF INQUIRY 
APPENDIX A

LETTER OF INQUIRY

Dear

TECHNICAL EVALUATION OF DRAFT ANSI STANDARD N13.30

Thank you for your past interest in the DOE bioassay intercomparison study. As you are aware, the purpose of this program is to evaluate the appropriateness of performance criteria in draft ANSI Standard N13.30, "Performance Criteria of Radiobioassay," by measuring the ability of existing bioassay laboratories to meet the criteria specified in that standard. The end result of the testing program will be a manual that recommends procedures and criteria for the accreditation of laboratories providing bioassay services.

We will soon have an artificial fecal test matrix spiked with plutonium available to participants as part of the final phase of the in-vitro testing portion of the program. Participant identification and the data provided for this program will be held in the strictest confidence. The artificial matrix material will contain inorganic and biological constituents in approximate physiological amounts. We would greatly appreciate receiving your specific comments regarding this option.

Your cooperation is essential for the development of a workable standard and meaningful recommendations for a good accreditation procedure. If you are interested in participating in the fecal testing program, please complete and return the attached form. We will be contacting the responding facilities to verify their interest in the program.

Sincerely,

Jay A. MacLellan

Senior Research Scientist

Health Physics Technology Section

HEALTH PHYSICS DEPARTMENT
Richard J. Traub

Senior Research Scientist Dosimetry Technology Section HEALTH PHYSICS DEPARTMENT

JAM/RJT : 1 em

Attachment 
Return to:

Pacific Northwest Laboratory

Health Physics Department

RTL Building

P.0. Box 999

Richland, WA 99352

Attention: JA MacLellan/RJ Traub

Yes, we may be interested in participating in the fecal analysis program. Please contact me and provide more details.

Technical contact

Telephone

Facility name

Comments:

A.2 
APPENDIX B

IN VITRO MEASUREMENTS REPORT FORM 
APPENDIX B

IN VITRO MEASUREMENTS REPORT FORM

Name of Laboratory and/or Code Letter

Contact Person Phone

Date of Receipt Date of Analysis

Apparatus/Instrumentation Used:

\begin{tabular}{ccccccc} 
Sample & Total & Count & Background & Counting & pCi/ & Est. \\
No. & Counts & Time & Count Rate & Efficiency & Recovery Sample & Error \\
\hline
\end{tabular}

$\mathrm{S}_{\mathrm{b}}=$ $\mathrm{pCi}$ (estimated error for the procedure)

MDA $=$ $\mathrm{pCi}$

Please return this form and requested procedures to:

J. A. MacLellan

Pacific Northwest Laboratory

P.0. Box 999

Richland, WA 99352 
APPENDIX C

PROPAGATION OF ERROR IN

SPIKED ARTIFICIAL FECAL SAMPLES 


\section{PROPAGATION OF ERROR IN SPIKED ARTIFICIAL FECAL SAMPLES}

The methods used to estimate the total error in the in vitro test samples were the same as those discussed by Kanipe (1977). Briefly, we assumed that the individual components of the total error were independent, normally distributed variables and that propagation of error for the manipulation of various functions could be expressed as below.

$$
\begin{aligned}
& \text { Function } \\
& Q=X \pm Y \\
& \begin{array}{l}
\frac{\text { Error Formula }}{\sigma Q=\left(\sigma_{X}{ }^{2}+\sigma_{y}{ }^{2}\right) \frac{1}{2}} \\
\sigma Q=\left(a^{2} \sigma_{X}{ }^{2}+b^{2} \sigma_{y}{ }^{2}\right)^{\frac{1}{2}} \\
\sigma Q=X Y\left(\sigma_{X}{ }^{2} / X^{2}+\sigma_{y}{ }^{2} / Y^{2}\right) \frac{1}{2} \\
\sigma Q=X / Y\left(\sigma_{X}{ }^{2} / X^{2}+\sigma_{y}{ }^{2} / Y^{2}\right)^{\frac{1}{2}}
\end{array} \\
& Q=a X \pm b Y \\
& Q=X Y \\
& Q=X / Y
\end{aligned}
$$

Using the error formulas above, the equations for the dilution steps, and the error estimates quoted in the National Bureau Standards certificates supplied for each nuclide, the total error in the prepared samples was estimated. 


\section{APPENDIX D}

PARTICIPANT-SUPPLIED DATA 
- APPENDIX D

TABLE D.1. PARTICIPANT-SUPPLIED DATA

\begin{tabular}{|c|c|c|c|c|c|c|c|c|c|c|}
\hline \multicolumn{2}{|c|}{$\begin{array}{c}\text { Laboratory } \\
\text { Code }\end{array}$} & $\begin{array}{l}\text { Sample } \\
\text { Number } \\
\end{array}$ & $\begin{array}{l}\text { Total } \\
\text { Counts } \\
\end{array}$ & $\begin{array}{c}\text { Count Time, } \\
\text { min }\end{array}$ & $\begin{array}{l}\text { Background, } \\
\text { cpm }\end{array}$ & $\begin{array}{c}\text { Counting } \\
\text { Efficiency } \\
\end{array}$ & $\begin{array}{l}\text { Chemical } \\
\text { Recovery }\end{array}$ & $\begin{array}{c}\text { Assay, } \\
\mathrm{pCi} \\
\end{array}$ & $\begin{array}{l}\text { Percent } \\
\text { Error } \\
\end{array}$ & MDA \\
\hline \multirow{20}{*}{$\stackrel{\square}{ }$} & A & 1 & 1 & 1000.00 & 0.001 & 0.25 & 0.54 & 0.042 & -..- & 0.05 \\
\hline & A & 2 & 1 & 1000.00 & 0.001 & 0.22 & 0.65 & 0.035 & --.- & 0.05 \\
\hline & A & 3 & 6 & 1000.00 & 0.003 & 0.27 & 0.79 & 0.029 &.-- & 0.05 \\
\hline & A & 4 & 3 & 1000.00 & 0.001 & 0.23 & 0.56 & 0.041 & --- & 0.05 \\
\hline & A & 5 & 3 & 1000.00 & 0.001 & 0.24 & 0.43 & 0.054 & $-\cdots$ & 0.05 \\
\hline & A & 51 & 356 & 1000.00 & 0.001 & 0.21 & 0.53 & 1.21 & 14.1 & 0.05 \\
\hline & A & 52 & 336 & 1000.00 & 0.000 & 0.22 & 0.49 & 1.23 & 14.6 & 0.05 \\
\hline & A & 53 & 478 & 1000.00 & 0.003 & 0.26 & 0.65 & 1.32 & 12.4 & 0.05 \\
\hline & A & 54 & 321 & 1000.00 & 0.002 & 0.25 & 0.51 & 1.14 & 14.7 & 0.05 \\
\hline & A & 55 & 310 & 1000.00 & 0.002 & 0.22 & 0.49 & 1.13 & 14.9 & 0.05 \\
\hline & A & 101 & 3138 & 1000.00 & 0.003 & 0.27 & 0.55 & 0.20 & 9.8 & 0.05 \\
\hline & A & 102 & 3085 & 1000.00 & 0.001 & 0.23 & 0.60 & 9.24 & 9.4 & 0.05 \\
\hline & A & 103 & 3169 & 1000.00 & 0.001 & 0.24 & 0.57 & 10.10 & 9.7 & 0.05 \\
\hline & A & 104 & 3260 & 1000.00 & 0.001 & 0.21 & 0.52 & 11.20 & 10.0 & 0.05 \\
\hline & A & 105 & 2844 & 1000.00 & 0.000 & 0.22 & 0.52 & 9.87 & 10.1 & 0.05 \\
\hline & $F$ & 26 & 1 & 3333.33 & 0.0002 & 0.274 & 0.765 & 0.0003 & 100.0 & 0.0051 \\
\hline & $F$ & 27 & 0 & 3333.33 & 0.0008 & 0.270 & 0.870 & 0.0000 & 100.0 & 0.0051 \\
\hline & $F$ & 28 & 7 & 3333.33 & 0.0005 & 0.274 & 0.711 & 0.0038 & 50.6 & 0.0051 \\
\hline & $F$ & 29 & 8 & 3333.33 & 0.0011 & 0.297 & 0.604 & 0.0034 & 69.4 & 0.0051 \\
\hline & $F$ & 30 & 3 & 3333.33 & 0.0009 & 0.288 & 0.805 & 0.0000 & 100.0 & 0.0051 \\
\hline
\end{tabular}


TABLE D.1. (contd)

\begin{tabular}{|c|c|c|c|c|c|c|c|c|c|}
\hline $\begin{array}{c}\text { Laboratory } \\
\text { Code }\end{array}$ & $\begin{array}{l}\text { Sample } \\
\text { Number } \\
\end{array}$ & $\begin{array}{l}\text { Total } \\
\text { Counts } \\
\end{array}$ & $\begin{array}{c}\text { Count Time, } \\
\min \end{array}$ & $\begin{array}{c}\text { Background, } \\
\text { cpm }\end{array}$ & $\begin{array}{l}\text { Counting } \\
\text { Efficiency }\end{array}$ & $\begin{array}{l}\text { Chemical } \\
\text { Recovery }\end{array}$ & $\begin{array}{c}\text { Assay, } \\
\text { pCi } \\
\end{array}$ & $\begin{array}{l}\text { Percent } \\
\text { Error } \\
\end{array}$ & MDA \\
\hline $\mathrm{F}$ & 76 & 1766 & 3333.33 & 0.0006 & 0.244 & 0.951 & 1.0278 & 2.4 & 0.0051 \\
\hline $\mathrm{F}$ & 77 & 1898 & 3333.33 & 0.0011 & 0.264 & 0.891 & 1.0882 & 2.3 & 0.0051 \\
\hline $\mathrm{F}$ & 78 & 1560 & 3333.33 & 0.0009 & 0.272 & 0.783 & 0.9879 & 2.5 & 0.0051 \\
\hline $\mathrm{F}$ & 79 & 1616 & 3333.33 & 0.0000 & 0.284 & 0.702 & 1.0950 & 2.5 & 0.0051 \\
\hline $\mathrm{F}$ & 80 & 1563 & 3333.33 & 0.0080 & 0.291 & 0.672 & 1.0784 & 2.5 & 0.0051 \\
\hline $\mathrm{F}$ & 126 & 14850 & 3333.33 & 0.0008 & 0.256 & 0.935 & 8.3834 & 82.1 & 0.0051 \\
\hline $\mathrm{F}$ & 127 & 12172 & 3333.33 & 0.0003 & 0.274 & 0.724 & 8.2849 & 90.6 & 0.0051 \\
\hline $\mathrm{F}$ & 128 & 13054 & 3333.33 & 0.0008 & 0.270 & 0.831 & 7.8579 & 87.5 & 0.0051 \\
\hline is & 129 & 8159 & 3333.33 & 0.0005 & 0.274 & 0.586 & 6.8681 & 111.0 & 0.0051 \\
\hline$F$ & 130 & 7622 & 3333.33 & 0.0011 & 0.297 & 0.435 & 7.6537 & 115.0 & 0.0051 \\
\hline G & 31 & 5 & 720.00 & 0.000 & 0.201 & 0.425 & -0.01 & 500.0 & 0.12 \\
\hline G & 32 & 20 & 720.00 & 0.002 & 0.210 & 0.420 & 0.0045 & 1300.0 & 0.12 \\
\hline G & 33 & 100 & 720.00 & 0.0008 & 0.224 & 0.390 & 0.54 & 12.3 & 0.12 \\
\hline G & 34 & 3 & 720.00 & 0.0008 & 0.199 & 0.451 & -0.12 & 33.3 & 0.12 \\
\hline G & 35 & 13 & 720.00 & 0.0008 & 0.213 & 0.464 & -0.08 & 62.5 & 0.12 \\
\hline$G$ & 81 & 160 & 720.00 & 0.0003 & 0.300 & 0.290 & 1.01 & 8.9 & 0.12 \\
\hline G & 82 & 198 & 720.00 & 0.0000 & 0.212 & 0.494 & 1.04 & 8.7 & 0.12 \\
\hline G & 83 & 240 & 720.00 & 0.0013 & 0.208 & 0.501 & 1.30 & 6.9 & 0.12 \\
\hline G & 84 & 243 & 720.00 & 0.0013 & 0.119 & 0.783 & 1.48 & 6.8 & 0.12 \\
\hline$G$ & 85 & 210 & 720.00 & 0.0010 & 0.211 & 0.440 & 1.26 & 7.1 & 0.12 \\
\hline
\end{tabular}




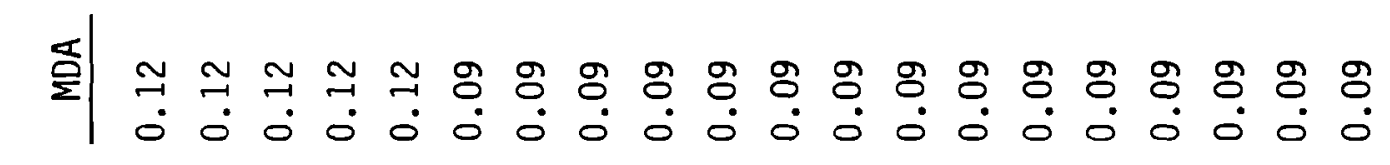

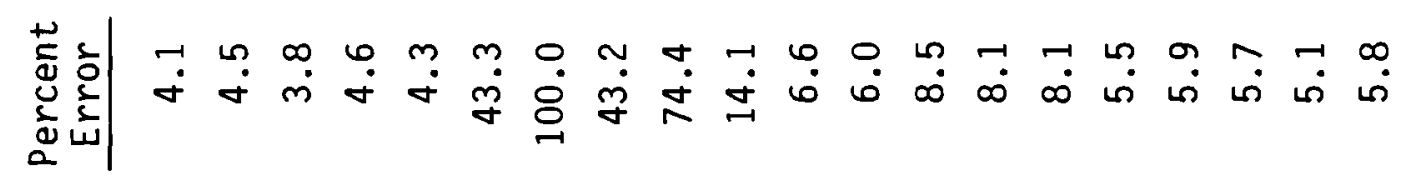

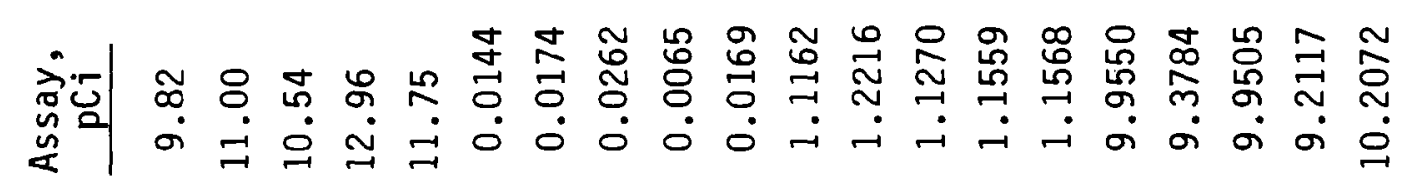

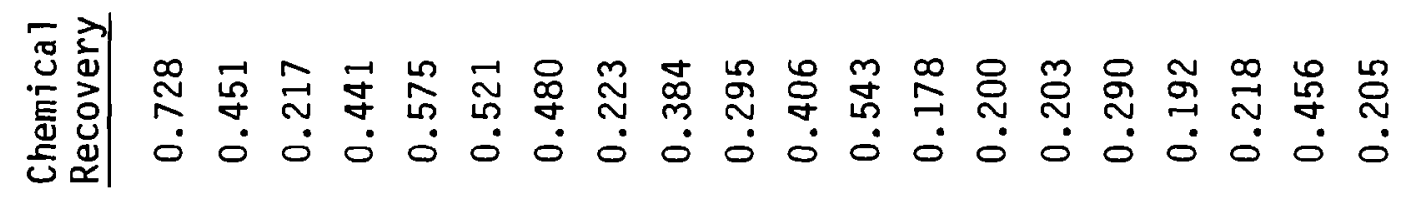

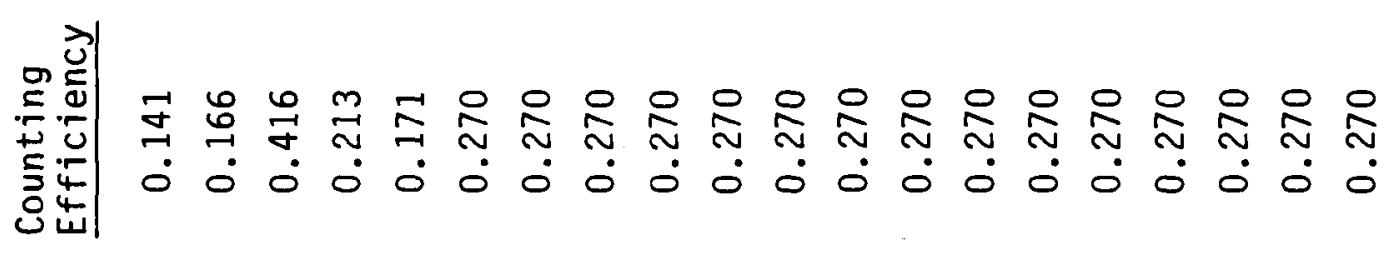

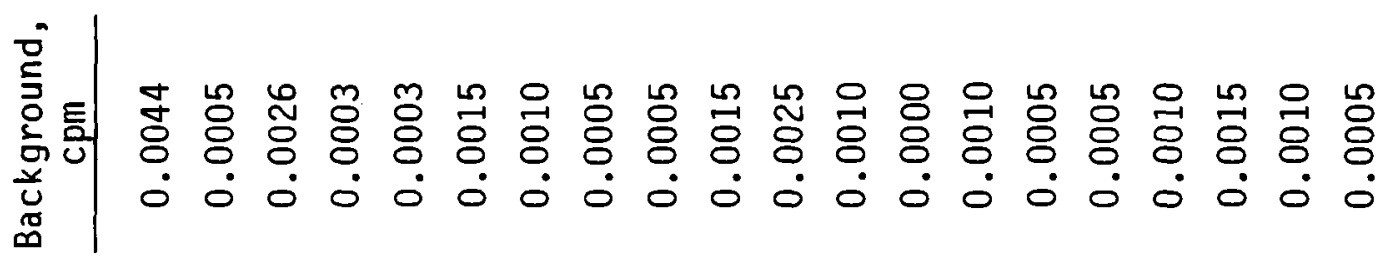

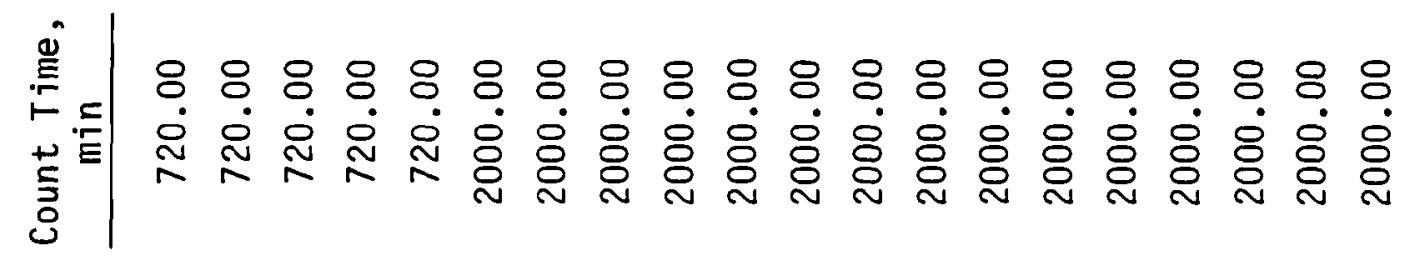

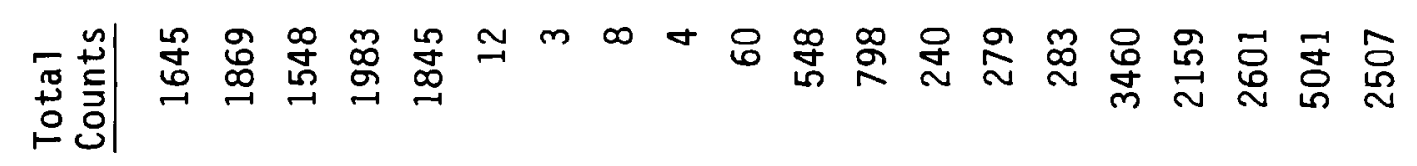

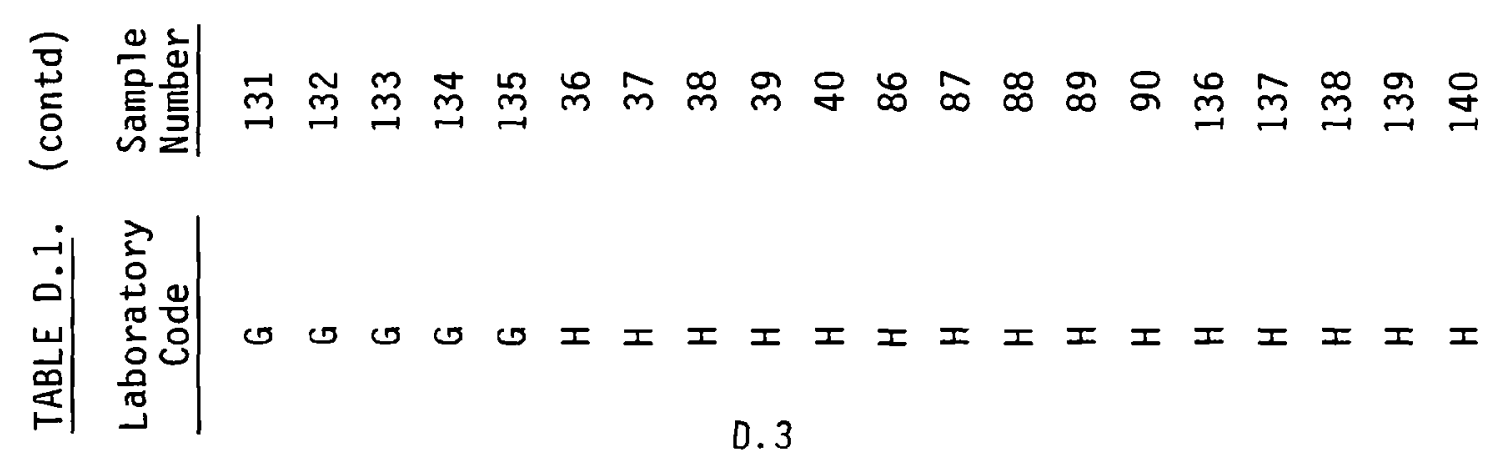


TALBE D.1. (contd)

\begin{tabular}{|c|c|c|c|c|c|c|c|c|c|}
\hline $\begin{array}{c}\text { Laboratory } \\
\text { Code }\end{array}$ & $\begin{array}{l}\text { Sample } \\
\text { Number } \\
\end{array}$ & $\begin{array}{l}\text { Total } \\
\text { Counts } \\
\end{array}$ & $\begin{array}{c}\text { Count Time, } \\
\quad \min \end{array}$ & $\begin{array}{c}\text { Background, } \\
\mathrm{cpm}\end{array}$ & $\begin{array}{l}\text { Counting } \\
\text { Efficiency }\end{array}$ & $\begin{array}{l}\text { Chemical } \\
\text { Recovery }\end{array}$ & $\begin{array}{c}\text { Assay, } \\
\mathrm{pCi} \\
\end{array}$ & $\begin{array}{l}\text { Percent } \\
\text { Error }\end{array}$ & MDA \\
\hline I & 41 & 2 & 1000.00 & 0.005 & 0.299 & 0.867 & -0.005 & 120.0 & 0.02 \\
\hline I & 43 & 5 & 1000.00 & 0.005 & 0.297 & 0.861 & 0.000 & 100.0 & 0.02 \\
\hline I & 45 & 13 & 3000.00 & 0.006 & 0.289 & 0.869 & -0.003 & 100.0 & 0.02 \\
\hline I & 92 & 1934 & 3000.00 & 0.002 & 0.278 & 0.897 & 1.158 & 4.6 & 0.02 \\
\hline 1 & 93 & 704 & 1000.00 & 0.006 & 0.289 & 0.932 & 1.169 & 7.6 & 0.02 \\
\hline I & 94 & 354 & 1000.00 & 0.002 & 0.278 & 0.480 & 1.186 & 10.6 & 0.02 \\
\hline
\end{tabular}

. 


\section{DISTRIBUTION}

No. of

Copies

OFFSITE

10. DOE/Office of Scientific and Technical Information

DOE Headquarters

R. P. Berube, Deputy Assistant

Director for Environment

U.S. Department of Energy

Washington, DC 20545

J. D. Foulke

Office of Nuclear Safety

U.S. Department of Energy

Washington, DC 20545

J. P. Knight, Director

Office of Nuclear Safety

U.S. Department of Energy

Washington, DC 20545

Bette L. Murphy

Office of Nuclear Safety

U.S. Department of Energy

Washington, DC 20545

D. R. Nelson

Office of Nuclear Safety

U.S. Department of Energy

Washington, DC 20545

R. W. Starostecki, Assistant Secretary for Safety, Health, and Quality Assurance

U.S. Department of Energy

Washington, DC 20545

10 E. J. Vallario, Acting Director Radiological Controls Division U.S. Department of Energy Washington, DC 10545
No. of

Copies

Assistant Secretary for

Environment, Safety, and

Health

U.S. Department of Energy

Washington, DC 20545

DOE Albuquerque Operations Office

R. E. Alexander

Pantex Plant

Mason \& Hanger--Silas Mason Co., Inc.

P.0. Boix 30020

Amari110, TX 79177

W. D. Burnett

DOE Sandia Nationa 1 Laboratories

Ma 17 Code 3312, B1dg. 8619

P.0. Box 2800

Albuquerque, NM 87115

G. W. Campbe11

Rockwell International

Rocky Flats Plant

P.0. Box 464

Golden, C0 80401

J. W. Doty

Mound Laboratory

Monsanto Research Corporation

Miamisburg, $\mathrm{OH} 45342$

R. Falk

Rockwell International

Rocky Flats Plant

P.0. Box 464

Golden, CO 80401

W. D. Moss

Los Alamos National Laboratory

P.0. Box 1663

Los Alamos, NM 87545 
No. of

Copies

P. M. Ramey

U.S. Department of Energy

Albuquerque Operations Office P.0. Box 5400

Aibuquerque, NM 87115

R. G. Stafford

Los Alamos National Laboratory

P.0. Box 1663

Los Alamos, NM 87545

J. G. Themelis

U.S. Department of Energy

Albuquerque Operations Office

P.0. Box 5400

Albuquerque, NM 87115

DOE Chicago Operations Office

L. V. Coutson

Fermi National Accelerator Laboratory

P.0. Box 500

Batavia, IL 60510

R. A. Mayes

U.S. Department of Energy

9800 South Cass Avenue

Argonne, IL 60439

C. B. Meinhold

Brookhaven National Laboratory

Associated Universities, Inc.

Upton, NY 11973

D. P. O'Neil

Argonne National Laboratory

9800 South Cass Avenue

Argonne, IL 60439

DOE Idaho Operations Office

J. H. Barry

U.S. Department of Energy

Idaho Operations Office

785 DOE Place

Idaho Falls, ID 83402
No. of

Copies

B. L. Rich

EG\&G I daho

P.0. Box 1625

Idaho Falls, ID 83401

A. N. Tschaeche

WINCO

$M / S$ CPP -630

P.0. Box 4000

Idaho Falls, ID 83403

DOE Nevada Operations Office

A. E. Bicker

Reynolds Electrical \& Engineering, Co., Inc.

P.0. Box 14400

Las Vegas, NY 89114

P. K. Fitzsimmons

U.S. Department of Energy

Nevada Operations Office

P.0. Box 14100

Las Vegas, NY 89114

DOE Oak Ridge Operations Office

R. J. Cloutier

Oak Ridge Associated Universities

P.0. Box 117

Oak Ridge, TN 37831

R. E. Halliburton

Oak Ridge National Laboratory

P.0. Box $X$

Oak Ridget, TN 38730

S. L. Hinnefeld

Westinghouse Matgerials Co. of Ohio

P.0. Box 398704

Cincinnati, $\mathrm{OH} 45239$

D. B. Howard

U.S. Department of Energy

Oak Ridge Operations Office

P.0. Box E

Oak Ridge, TN 37831 
No. of

Copies

W. T. Mee

$Y-12$

P.0. Box $Y$

Oak Ridge, TN 37830

D. C. Parzyck

Oak Ridge National Laboratory

P.0. Box $X$

Oak Ridge, TN 37830

S. F Seltzer

Paducah Gaseous Diffusion Plant

P.0. Box P

Oak Ridge, TN 37831

J. E. Shoemaker

Oak Ridge Gaseous Diffusion Plant

P.0. Box $P$

Oak Ridge, TN 37831

F. G. VanLoocke

RMI Company

P.0. Box 579

Ashtabula, $\mathrm{OH} 44004$

E. R. Wagner

Portsmouth Gaseous Diffusion Plant

Martin Marietta Energy Systems

P.0. Box 628

Piketon, $\mathrm{OH} 45661$

DOE San Francisco Operations

Office

T. R. Crites

Lawrence Livermore National Laboratory

P.0. Box 5505

Livermore, CA 94550

J. T. Davis

U.S. Department of Energy

San Francisco Operations Office

1333 Broadway

Oakland, CA 94612
No. of

Copies

\author{
R. C. McCal1 \\ Stanford Linear Accelerator \\ P.0. Box 4349 \\ Stanford, CA 94305 \\ R. G. Thomas \\ DOE Lawrence Berkeley National \\ Laboratory \\ University of California \\ Berkeley, CA 94720 \\ G. Warren \\ Stanford Linear Accelerator \\ P.0. Box 4349 \\ Stanford, CA 94305 \\ DOE Savannah River Operations \\ Office
}

D. N. Bridges

U.S. Department of Energy

Savannah River Operations Office

P.0. Box A

Aiken, SC 29809

W. C. Reinig

E. I. duPont de Nemours \& Co.

Savannah River Plant

Aiken, SC 29809

EPA Office of Radiation Programs

A. Richardson

401 M Street, SW

Washington, DC 20460

Nationa 1 Center for Devices and Radiological Health

J. C. Villforth

FDA Bureau of Radiological Health Rockville, MD 20852

National Bureau of Standards

E. H. Eisenhower

National Bureau of Standards

Gaithersburg, MD 20899 
No. of

Copies

$R$. Loevinger

National Bureau of Standards

Gaithersburg, MD 20899

Nuclear Regulatory Commission

R. E. Alexander

U.S. Nuclear Regulatory Commission

Washington, DC 20555

\section{OTHER}

A. Brodsky

16412 Kipling Road

Derwood, MD 20855

F. Bronson

Canberra/RMC

One State Street

Meriden, CT 06450

K. R. Heid

2318 Davison Avenue

Richland, WA 99352

D. McCurdy

Yankee Atomic Electric Co.

1671 Worcester Road

Framingham, MA 01701

R. Mellor

Yankee Atomic Electric Co.

1671 Worcester Road

Framingham, MA 01701

M. Ortiz

Eberline Analytical

P.0. Box 3874

Aibuquerque, NM 87190
No. of

Copies

B. Wessman

TMA/Norca 1

2030 Wright Avenue

Richmond, CA 94804

ONSITE

2 DOE Richland Operations Office

D. T. Evans

D. L. Sours

Westinghouse Hanford Company

R. 0. Budd

2 U.S. Testing Company, Inc.

M. M. Lardy

A. V. Robinson

64 Pacific Northwest Laboratory

W. J. Bair

L. W. Brackenbush

J. T. Denovan

L. G. Faust

D. R. Fisher

G. R. Hoenes

J. A. MacLellan (15)

J. B. Martin

J. M. Selby (30)

K. L. Soldat

K. L. Swinth

R. J. Traub

M. T. Upton

Health Physics Department Library

Publishing Coordination (2)

Technical Report Files (5) 